Bisbenzylisoquinoline alkaloids as markers of Atherospermataceae tetrandrine and fangchinoline from Laureliopsis philippiana

Stanstrup, Jan; Schmidt, Jeppe Secher; Rasmussen, Hasse Bonde; Mølgaard, Per; Guzmán, Alfonso; Stærk, Dan

Published in:

Biochemical Systematics and Ecology

DOI:

10.1016/j.bse.2010.03.006

Publication date:

2010

Document version

Early version, also known as pre-print

Citation for published version (APA):

Stanstrup, J., Schmidt, J. S., Rasmussen, H. B., Mølgaard, P., Guzmán, A., \& Stærk, D. (2010).

Bisbenzylisoquinoline alkaloids as markers of Atherospermataceae: tetrandrine and fangchinoline from Laureliopsis philippiana. Biochemical Systematics and Ecology, 38(3), 450-453.

https://doi.org/10.1016/j.bse.2010.03.006 


\title{
Bisbenzylisoquinoline alkaloids as markers of Atherospermataceae: Tetrandrine and fangchinoline from Laureliopsis philippiana
}

\author{
Jan Stanstrup $^{\mathrm{a}, \mathrm{b}}$, Jeppe S. Schmidt ${ }^{\mathrm{a}, \mathrm{b}}$, Hasse B. Rasmussen ${ }^{\mathrm{a}}$, \\ Per Mølgaard ${ }^{\mathrm{a}}$, Alfonso Guzmán ${ }^{\mathrm{a}}$, Dan Staerk ${ }^{\mathrm{b}, *}$ \\ ${ }^{a}$ Department of Medicinal Chemistry, Faculty of Pharmaceutical Sciences, University of Copenhagen, Universitetsparken 2, DK-2100 Copenhagen, Denmark \\ ${ }^{\mathrm{b}}$ Department of Basic Sciences and Environment, Faculty of Life Sciences, University of Copenhagen, Thorvaldsensvej 40, DK-1871 Frederiksberg, Denmark
}

\section{A R T I C L E I N F O}

\section{Article history:}

Received 7 January 2010

Accepted 13 March 2010

\section{Keywords:}

Laureliopsis philippiana

Atherospermataceae

Bisbenzylisoquinoline alkaloid

Tetrandrine

Fangchinoline

\section{Subject and source}

Laureliopsis philippiana (Looser) Schodde [syn. Laurelia serrata Phil. and Laurelia philippiana Looser] is a slow growing, shade tolerant tree that is native to Chile and Argentina (Veblen et al., 1996; Lusk, 1999). The tree is also known as Tepa, and extracts of the leaves have traditionally been used by the Chilean Mapuche people for the treatment of colds and headaches (Houghton and Manby, 1985). Laureliopsis is a monotypic genus that used to be included in Monimiaceae; however based on phylogenetic studies Monimiaceae has been reorganized into Monimiaceae sensu stricto, Siparunaceae, and Atherospermataceae, with L. philippiana included in the latter (Renner, 1998, 1999, 2004; Renner et al., 2000). In this study, leaves were collected in Chile (coastal area close to Pucomo, Osorno) in October 2006 by Alfonso Guzmán. A voucher specimen (accession number: PM2001/5) has been deposited in Herbarium C (Botanical Museum, University of Copenhagen, Copenhagen, Denmark) as well as at Universidad de los Lagos, Osorno, Chile.

\section{Previous work}

Previous investigations of stem bark resulted in isolation of $S-(+)$-reticuline, $R-(-)$-asimilobine, $R-(-)$-anonaine, $S$ - $(+)-$ norcorydine, $S-(+)$-nornantenine, $(4 S, 6 \mathrm{a} S)$-4-hydroxynornantenine, $\left(4 R^{*}, 6 \mathrm{a} R^{*}\right)$-4-hydroxyanonaine, liriodenine, atheroline, oxonantenine, laurotetanine, and norisocorydine (Urzúa et al., 1975; Urzúa and Cassels, 1978a, 1978b, 1982), and it was not until recently that laureliopsine A, a 6',7-epoxy analogue of the berbamine subgroup, was identified in a leaf extract (Staerk et al., 2009). Another study investigated the fungistatic activity of essential oils of leaves of L. philippiana (Bittner et al., 2009).

\footnotetext{
* Corresponding author. Tel.: +45 35332425; fax: +45 35332398.

E-mail address: dst@life.ku.dk (D. Staerk).
} 


\section{Present study}

Powdered leaves (197.5 g) of $L$. philippiana were extracted 5 times successively with $600 \mathrm{~mL}$ of $\mathrm{CH}_{2} \mathrm{Cl}_{2}-\mathrm{MeOH}(1: 1)$. The extract was evaporated under reduced pressure below $40{ }^{\circ} \mathrm{C}$ to yield $31.6 \mathrm{~g}$ of dry crude extract. The residue was dissolved in $1 \mathrm{~L}$ of $0.25 \mathrm{~N} \mathrm{H}_{2} \mathrm{SO}_{4}$, filtered and extracted twice with $250 \mathrm{~mL}$ heptane and three times with $330 \mathrm{~mL}$ EtOAc. The aqueous layer was basified ( $\mathrm{pH} 11$ ) using $25 \% \mathrm{NH}_{4} \mathrm{OH}$ and extracted four times with $300 \mathrm{~mL}$ of EtOAc. The latter ethyl acetate extract was extracted with $300 \mathrm{~mL} 25 \% \mathrm{NH}_{4} \mathrm{OH}$ and was evaporated as described above to yield $2.60 \mathrm{~g}$ of crude alkaloids.

Semi-preparative HPLC separations of the alkaloid fraction were performed at $40{ }^{\circ} \mathrm{C}$ on a Phenomenex $\mathrm{C}_{18}(2)$ Luna column $(150 \times 10 \mathrm{~mm}$ i.d., particle size $3 \mu \mathrm{m})$ with a flow rate of $2.5 \mathrm{ml} / \mathrm{min}$ using a mixture of $\mathrm{H}_{2} \mathrm{O} / \mathrm{MeOH} \mathrm{95:5+0.1 \%} \mathrm{formic} \mathrm{acid}$ (eluent A) and $\mathrm{MeOH} / \mathrm{H}_{2} \mathrm{O} 95: 5+0.1 \%$ formic acid (eluent B). Nineteen repeated separations (injection volumes of $100 \mu \mathrm{l}$ of a $3 \mathrm{mg} / \mathrm{mL}$ solution) were performed using the following gradient profile: $0 \mathrm{~min}, 20 \% \mathrm{~B} ; 8 \mathrm{~min}, 20 \% \mathrm{~B} ; 9 \mathrm{~min}, 100 \% \mathrm{~B} ; 16 \mathrm{~min}$, $100 \% \mathrm{~B} ; 17 \mathrm{~min}, 20 \% \mathrm{~B} ; 25 \mathrm{~min}, 20 \% \mathrm{~B}$ to afford $24.1 \mathrm{mg}$ of $\mathbf{1}$ and $6.4 \mathrm{mg}$ of 2.

Compound 1 was obtained as a yellowish gum with specific rotation $[\alpha]^{25} \mathrm{D}$ of $+198.8\left(c 0.50, \mathrm{CH}_{2} \mathrm{Cl}_{2}\right)$, and ${ }^{1} \mathrm{H}$ and ${ }^{13} \mathrm{C} \mathrm{NMR} \mathrm{data}$ fully assigned by COSY, NOESY, HSQC and HMBC experiments acquired at $800 \mathrm{MHz}$ identified $\mathbf{1}$ as fangchinoline. Only partly assigned ${ }^{1} \mathrm{H}$ and ${ }^{13} \mathrm{C}$ NMR data have previously been reported for fangchinoline (Philipov and Istatkova, 1997; Lijin et al., 2009), and the fully assigned high field data are therefore given in Table 1.

Compound 2 was obtained as a yellowish gum with specific rotation $[\alpha]^{25}$ of $+201.5\left(c 0.49, \mathrm{CH}_{2} \mathrm{Cl}_{2}\right)$, and identified as tetrandrine based on ${ }^{1} \mathrm{H}$ NMR, ${ }^{13} \mathrm{C}$ NMR, COSY, NOESY, HSQC and HMBC experiments acquired at $800 \mathrm{MHz}$. The ${ }^{1} \mathrm{H}$ and ${ }^{13} \mathrm{C}$ NMR data are in agreement with those reported in the literature (Thevand et al., 2004).
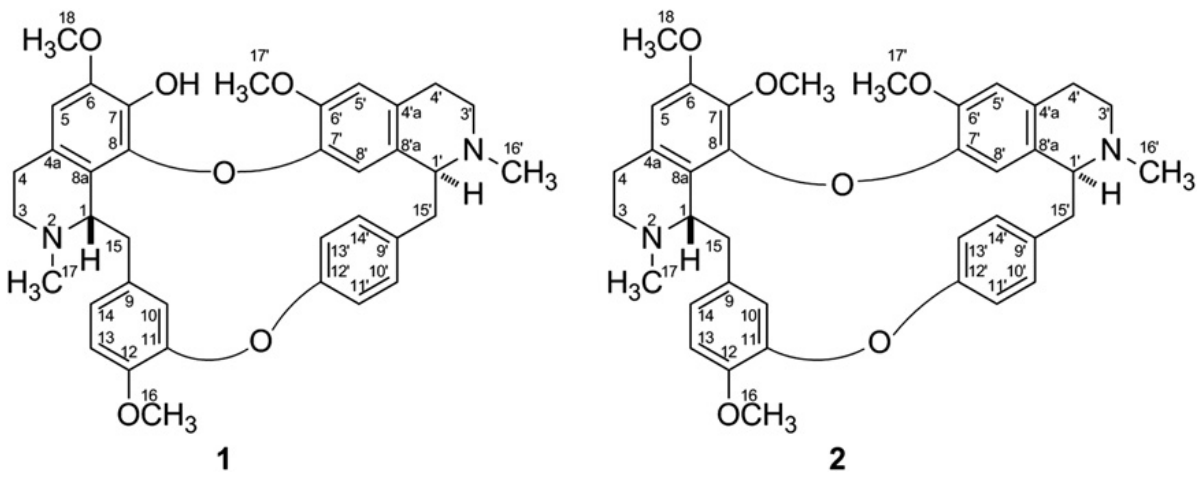

Table 1

${ }^{1} \mathrm{H}$ and ${ }^{13} \mathrm{C}$ NMR data of $\mathbf{1}$.

\begin{tabular}{|c|c|c|c|c|c|}
\hline Pos. & ${ }^{13} C^{a}$ & ${ }^{1} \mathrm{H}^{\mathrm{a}, \mathrm{b}}$ & Pos. & ${ }^{13} \mathrm{C}^{\mathrm{a}}$ & ${ }^{1} \mathrm{H}^{\mathrm{a}, \mathrm{b}}$ \\
\hline 1 & 61.8 & $4.04 \mathrm{br} \mathrm{d}\left(J_{\mathrm{H} 1-\mathrm{H} 15 \mathrm{~B}} \approx 10.0\right)$ & $1^{\prime}$ & 63.7 & $4.14 \mathrm{br} d d\left(J_{\mathrm{H} 1-\mathrm{H} 15 \mathrm{~B}} \approx 11.0 ; J_{\mathrm{H} 1-\mathrm{H} 15 \mathrm{~A}} \approx 4.5\right)$ \\
\hline 3 & 45.3 & $\begin{array}{l}\alpha: 3.04 \mathrm{~m} \\
\beta: 3.60 \mathrm{ddd}\left(J_{\mathrm{H} 3 \beta-\mathrm{H} 3 \alpha}=13.0 ; J_{\mathrm{H} 3 \beta-\mathrm{H} 4 \alpha}=\right. \\
\left.10.9 ; J_{\mathrm{H} 3 \beta-\mathrm{H} 4 \beta}=15.3\right)\end{array}$ & $3^{\prime}$ & 44.2 & $\begin{array}{l}\alpha: 3.16 \mathrm{br} d \mathrm{dd}\left(J_{\mathrm{H} 3 \alpha-\mathrm{H} 3 \beta} \approx 12.0 ; J_{\mathrm{H} 3 \alpha-\mathrm{H} 4 \beta} \approx 4.5\right) \\
\beta: 3.67 \mathrm{~m}\end{array}$ \\
\hline 4 & 23.0 & $\begin{array}{l}\alpha: 2.66 \mathrm{~m} \\
\beta: 2.96 \mathrm{~m}\end{array}$ & $4^{\prime}$ & 23.5 & $\begin{array}{l}\alpha: 2.94 \mathrm{~m} \\
\beta: 3.04 \mathrm{~m}\end{array}$ \\
\hline $4 a$ & 122.6 & & $4^{\prime} \mathrm{a}$ & 126.1 & \\
\hline 5 & 105.2 & $6.33 \mathrm{~s}$ & $5^{\prime}$ & 112.9 & $6.56 \mathrm{~s}$ \\
\hline 6 & 146.6 & & $6^{\prime}$ & 149.9 & \\
\hline 7 & 135.2 & & $7^{\prime}$ & 144.3 & \\
\hline 8 & 141.5 & & $8^{\prime}$ & 120.9 & 6.06 \\
\hline $8 a$ & 121.9 & & $8^{\prime} \mathrm{a}$ & 124.7 & \\
\hline 9 & 133.2 & & $9^{\prime}$ & 133.3 & \\
\hline 10 & 116.0 & $6.54 \mathrm{~d}\left(J_{\mathrm{H} 10-\mathrm{H} 14}=1.9\right)$ & $10^{\prime}$ & 132.7 & $6.32 \mathrm{dd}\left(J_{\mathrm{H} 10^{\prime}-\mathrm{H} 11^{\prime}}=8.2 ; J_{\mathrm{H}_{1} 0^{\prime}-\mathrm{H} 14^{\prime}}=2.0\right)$ \\
\hline 11 & 149.6 & & $11^{\prime}$ & 122.3 & $6.83 \mathrm{dd}\left(J_{\mathrm{H} 11^{\prime}-\mathrm{H} 13^{\prime}}=8.2 ; J_{\mathrm{H} 11^{\prime}-\mathrm{H} 10^{\prime}}=2.4\right)$ \\
\hline 12 & 147.8 & & $12^{\prime}$ & 154.4 & \\
\hline 13 & 111.9 & $6.85 \mathrm{~d}\left(J_{\mathrm{H} 13-\mathrm{H} 14}=8.2\right)$ & $13^{\prime}$ & 122.3 & $7.07 \mathrm{dd}\left(J_{\mathrm{H} 13^{\prime}-\mathrm{H} 11^{\prime}}=8.2 ; J_{\mathrm{H}_{13}{ }^{\prime}-\mathrm{H} 14^{\prime}}=2.4\right)$ \\
\hline 14 & 123.5 & $6.94 \mathrm{br} \mathrm{d}\left(\mathrm{H}_{\mathrm{H} 14-\mathrm{H} 13}=8.2\right)$ & $14^{\prime}$ & 130.6 & $7.36 \mathrm{br} \mathrm{d}\left(\mathrm{J}_{\mathrm{H} 14^{\prime}-\mathrm{H} 13^{\prime}}=8.2\right)$ \\
\hline 15 & 41.5 & $\begin{array}{l}\text { A: } 2.67 \mathrm{~d}\left(J_{\mathrm{H} 15 \mathrm{~A}-\mathrm{H} 15 \mathrm{~B}}=14.7\right) \\
\text { B: } 2.85 \mathrm{dd}\left(J_{\mathrm{H} 15 \mathrm{~A}-\mathrm{H} 15 \mathrm{~B}}=14.7 ; J_{\mathrm{H} 15 \mathrm{~A}-\mathrm{H} 1}=10.1\right)\end{array}$ & $15^{\prime}$ & 38.6 & $\begin{array}{l}\text { A: } 2.77 \mathrm{t}\left(J_{\mathrm{H} 15^{\prime} \mathrm{A}-\mathrm{H} 15^{\prime} \mathrm{B}}=J_{\mathrm{H} 15^{\prime} \mathrm{A}-\mathrm{H} 1^{\prime}}=11.8\right) \\
\text { B: } 3.50 \mathrm{~m}\end{array}$ \\
\hline 16 & 56.3 & $3.92 \mathrm{~s}$ & $16^{\prime}$ & 41.1 & $2.70 \mathrm{~s}$ \\
\hline 17 & 42.6 & $2.44 \mathrm{~s}$ & $17^{\prime}$ & 56.2 & $3.40 \mathrm{~s}$ \\
\hline 18 & 56.3 & $3.78 \mathrm{~s}$ & & & \\
\hline
\end{tabular}

a ${ }^{1} \mathrm{H}(800 \mathrm{MHz})$ and ${ }^{13} \mathrm{C}(200 \mathrm{MHz})$ NMR spectral data measured in chloroform- $d, \delta$ values relative to internal TMS.

b Multiplicity of signals is given in parentheses: $s$, singlet; $d$, doublet; $t$, triplet; $m$, multiplet; $b r$, broad; coupling constants (apparent splittings) are reported as numerical values in $\mathrm{Hz}$. 


\section{Chemotaxonomic importance}

Atherospermataceae is a small family of trees and shrubs belonging to Laurales. The family is, in its present form, separated from Monimiaceae s.s. and regarded as closely related to Gomortegaceae, a family of trees endemic to Chile (Schodde, 1970; Renner et al., 2000; Renner, 2004). Atherospermataceae comprise 16 species according to Mabberley (Mabberley, 2008) distributed over seven genera, i.e., Atherosperma (1), Laureliopsis (1), Laurelia (2), Nemuaron (1), Dryadodaphne (3), Daphnandra (6), and Doryphora (2). However, based on a search in The International Plant Name Index (The International Plant Name Index, 2010) and Tropicos (Tropicos.org, 2010) the number of species may be as high as 25 leaving out dubious taxa. Classification and phylogeny within Atherospermataceae have been intensively studied by Renner and coworkers; however, the results still seem to be ambiguous. Thus, in two separate studies based on molecular data from plastid genome regions, Laureliopsis was separated from Laurelia and found to form a clade with Nemuaron (Renner, 1998) and Nemuaron and Atherosperma (Renner, 1999), respectively. However, in two other studies (Renner et al., 2000; Renner, 2004), molecular data based on plastid gene regions and correlation with fossil records showed that Laureliopsis and Laurelia form a clade that was separated from Atherosperma and Nemuaron at least 83 million years ago. About 79.5 million years ago, Laurelia sempervirens separated from L. philippiana and Laurelia novae-zelandiae, the two latter constituting a sub-clade. Thus, this ambiguity shows that taxonomic classification should be considered a multiparametric discipline, and therefore classification based on information about the genome should preferably be complemented with information about the proteome and the metabolome, i.e., the biological endpoint of the genome and the proteome. The identification of bisbenzylisoquinoline alkaloids (BBIs) reported in this study, i.e., fangchinoline and tetrandrine, covers only a small part of the full metabolome of $L$. philippiana. However, bisbenzylisoquinoline alkaloids are important chemical markers of Atherospermataceae, and they have been subject to intensive investigations. Thus, a compilation of BBIs identified in Atherospermataceae (Schiff, 2000; Staerk et al., 2009) has been added as Supplementary Data. The alkaloids are ordered according to the structural types originally defined by Shamma and Moniot (Shamma and Moniot, 1976) and later given Roman numerals by Guha and coworkers (Guha et al., 1979), and the compilation shows that Atherosperma, Laureliopsis, and Laurelia produce BBIs of structural type VIII in addition to two BBIs of type VI and a single BBI of type XXVIII. These results support the connection between Laureliopsis and Atherosperma as well as Laurelia, as shown by the somewhat contradictionary results in the above-mentioned studies (Renner, 1998, 1999, 2004; Renner et al., 2000). It is interesting, however, that whereas fangchinoline and tetrandrine, isolated from leaves of $L$. philippiana in this work, belong to the $1 S, 1$ 'S-series, previous work with $L$. sempervirens led to isolation of isofangchinoline [syn. thalrugosine] (Cassels and Urzúa, 1985) and isotetrandrine (Bianchi et al., 1962) as well as oxyacanthine and obaberine (Cassels and Urzúa, 1985), all of which have been assigned to the $1 R, 1$ 'S-series. This supports the classification of L. philippiana [syn. L. serrata Phil. and L. philippiana Looser] into a monotypic genus separated from Laurelia.

In conclusion, this work demonstrates the importance of complementing genome-based classification with classical smallmolecule metabolome-based classification. The majority of studies of these rather complex BBIs from Atherospermataceae are however rather old, and future in-depth studies utilizing new fast and sensitive hyphenated techniques like HPLC-PDA-MSSPE-NMR (Pedersen et al., 2009) or utilizing modern multivariate metabolomics approaches (Agnolet et al., 2010) are expected to yield better data for multiparametric chemotaxonomic classification of Atherospermataceae.

\section{Acknowledgements}

The $800 \mathrm{MHz}$ NMR experiments were obtained using the Bruker Avance III spectrometer of the Danish Instrument Center for NMR Spectroscopy of Biological Macromolecules, and HPLC-equipment used for semi-preparative HPLC was purchased via a grant from The Carlsberg Foundation (Copenhagen).

\section{Appendix. Supplementary data}

Supplementary data associated with this article can be found, in the online version, at doi: 10.1016/j.bse.2010.03.006.

\section{References}

Agnolet, S., Jaroszewski, J.W., Verpoorte, R., Staerk, D., 2010. Metabolomics 6. doi:10.1007/s11306-009-0195-X. Bianchi, E., Garbarino, J.A., Gioria, F., 1962. Gazz. Chim. Ital. 92, 818.

Bittner, M., Aguilera, M.A., Hernández, V., Arbert, C., Becerra, J., Casanueva, M.E., 2009. Chilean J. Agric. Res. 69, 30

Cassels, B.K., Urzúa, A., 1985. J. Nat. Prod. 48, 671.

Guha, K.P., Mukherjee, B., Mukherjee, R., 1979. J. Nat. Prod. 42, 1.

Houghton, P.J., Manby, J., 1985. J. Ethnopharmacol. 13, 89.

Lijin, Z., Xiao, W., Liu, J., Wenjuan, D., Daijie, W., Yanling, G., 2009. Chromatographia 69, 959.

Lusk, C.H., 1999. Plant Ecol. 140, 111.

Mabberley, D.J., 2008. Mabberley's Plant-Book. Cambridge University Press.

Pedersen, M.M., Chukwujekwu, J.C., Lategan, C.A., Van Staden, J., Smith, P.J., Staerk, D., 2009. Phytochemistry 70, 601.

Philipov, S.A., Istatkova, R.S., 1997. Phytochemistry 44, 1591.

Renner, S.S., Foreman, D.B., Murray, D., 2000. Syst. Biol. 49, 579.

Renner, S.S., 1998. Perspect. Plant Ecol Evol. Syst. 1, 61.

Renner, S.S., 1999. Am. J. Bot. 86, 1301.

Renner, S.S., 2004. Biol. Skr. 55, 441. 
Schiff Jr., P.L., 2000. The bisbenzylisoquinoline alkaloids - A tabular review. In: Pelletier, S.W. (Ed.), Alkaloids: Chemical and Biological Perspectives, vol. 14. Pergamon, Oxford, p. 1.

Schodde, R., 1970. Taxon 19, 324.

Shamma, M., Moniot, J.L., 1976. Heterocycles 4, 1817.

Staerk, D., Thi, L.P., Rasmussen, H.B., Guzmán, A., Mølgaard, P., 2009. Fitoterapia 80, 112.

The International Plant Name Index. Published on the Internet at http://www.ipni.org (accessed 7.01.2010).

Thevand, A., Stanculescu, I., Mandravel, C., Woisel, P., Surpateanu, G., 2004. Spectrochim. Acta, Part A 60, 1825.

Tropicos.org. Published on the Internet at http://www.tropicos.org (accessed 7.01.2010).

Urzúa, A., Cassels, B.K., 1978a. Tetrahedron Lett. 30, 2649.

Urzúa, A., Cassels, B.K., 1978b. Lloydia 41, 98.

Urzúa, A., Cassels, B.K., 1982. Phytochemistry 21, 773.

Urzúa, A., Cassels, B.K., Sanchez, E., Comin, J., 1975. Ann. Asoc. Quim. Argent. 63, 259.

Veblen, T.T., Donoso, C., Kitzberger, T., Rebertus, A.J., 1996. Ecology of Southern Chilean and Argentinean Nothofagus Forests. In: Veblen, T.T., Hill, R.S., Read, J. (Eds.), The Ecology and Biogeography of Nothofagus Forests. Yale University Press, p. 293. 